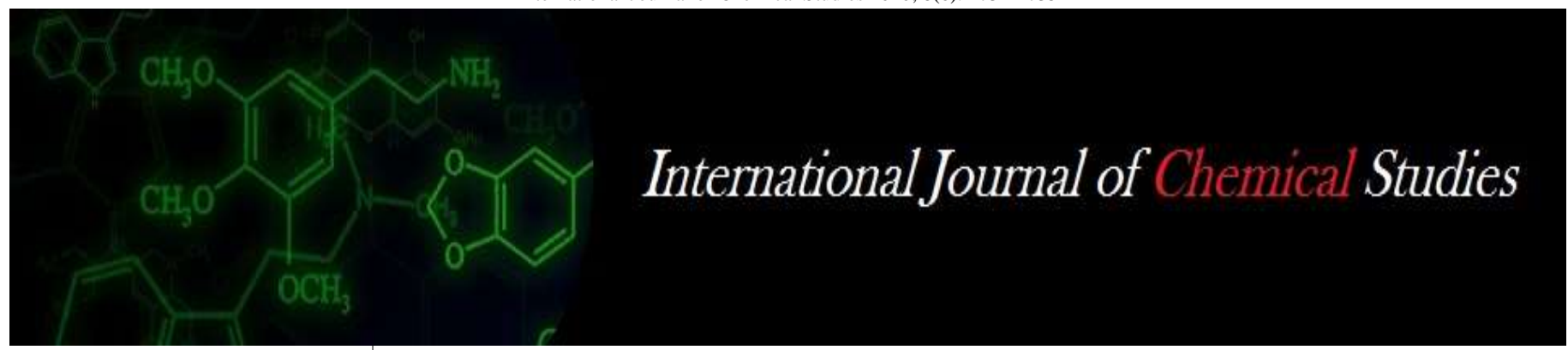

P-ISSN: 2349-8528

E-ISSN: 2321-4902

www.chemijournal.com

IJCS 2020; 8(6): 1731-1735

(C) 2020 IJCS

Received: 14-08-2020

Accepted: 25-10-2020

\section{Mamathad C}

M. Sc. Student, Department of

Entomology, College of

Agriculture, V. C. Farm,

Mandya, Karnataka, India

L Vijay Kumar

Professor of Entomology (OPG),

Department of Entomology,

College of Agriculture, V. C.

Farm, Mandya, Karnataka,

India

\section{Shivaray Navi}

Assistant Entomologist,

AICRP on Cotton, KVK,

Chamarajanagar, Karnataka,

India

Somu G

Assistant Breeder,

AICRP on Sorghum, KVK,

Chamarajanagar, Karnataka,

India

VB Sanathkumar

Professor of Plant Pathology, Department of Plant Pathology,

College of Agriculture, V. C.

Farm, Mandya, Karnataka,

India

\section{Survey on the incidence of Asian rice gall midge, Orseolia oryzae (Cecidomyiidae: Diptera) in Cauvery command area}

\author{
Mamathad C, L Vijay Kumar, Shivaray Navi, Somu G and VB \\ Sanathkumar
}

DOI: https://doi.org/10.22271/chemi.2020.v8.i6y.11015

\begin{abstract}
A survey was conducted on the incidence of gall midge in paddy ecosystem in Cuavery and Kabini command area, Karnataka. In Cauvery and Kabini command area mainly Jaya, Jyothi, MTU 1001, BR 2655, Tanu, Gangavathi sona are cultivated in which about $50 \%$ area is covered by Jaya. The crop is infested by gall midge which plays a significant role in limiting the rice production. During the survey along with gall midge other pests like yellow stem borer, hispa case worm, Leaf folder were noticed. Among the three districts surveyed Mandya districts has recorded higher gall midge infestation with per cent silver shoot of 9.03 , which was followed by Chamarajanagar $(8.70 \% \mathrm{SS})$. The lower gall midge infestation was noticed in the Mysore district with per cent silver shoot of 6.95. Due to the gall midge infestation the tiller become sterile and leads to yield loss. Early gall infestation in nursery results in the stunted growth and bushy appearance. Since gall midge being endoparasitic in nature, cultivation of resistant varieties is the most economical and feasible for its control.
\end{abstract}

Keywords: Rice gall midge, silver shoot, survey, incidence, status

\section{Introduction}

Rice (Oryza sativa L.) is the world's second most commonly consumed cereal after wheat. It is the essential food for two third of the world's population. World's 90 per cent of rice is cultivated and consumed in Asia only. Rice occupies an important place in Indian agriculture and is the major food source for more than 70 per cent of the world's population (Rai, 2006) [11]. It plays a key role in the livelihood of the rural families. It is the primary dietary source of nutrition for about 17 Asian and Pacific nation, 9 in South and North American countries and 8 in Africa. Rice provides about twenty per cent of the dietary energy supply. Rice occupies over one fourth of the total area cultivated and provides food to over half of the Indian population (Khush, 1997) ${ }^{[5]}$. In India, rice is cultivated under widely varying altitude and climatic conditions. Hot and humid climate is very much suited for paddy cultivation. Rice is usually suited to a region with higher humidity and sunshine with an assured irrigation (Chang, 1976) ${ }^{[2]}$. Number of biotic and abiotic constraints in rice production that regulates the yield competence and leading to a significant depletion in both quality and quantity. Among biotic factors, the major limitation for production of rice is insect-pest damage which is one of the important restraining factor in the cultivation of rice and results in yield loss in field and storage which accounts for about 24.00 per cent (Krishnaiah and Kalode 1986) ${ }^{[6]}$. Among insect pest of rice, the Asian rice gall midge ranked first among the twelve insect pests. At present it is considered as major insect pest in India, because of its relative importance. In India, gall midge was recorded from all the rice growing states except Western Uttar Pradesh, Punjab, Uttaranchal, Hill States, Himachal Pradesh, Haryana and Jammu and Kashmir (Bentur et al., 2003) ${ }^{[1]}$. The adult midge fly resembles a mosquito. Females are bigger as compared to male with marked difference among two sexes. Upon hatching from the eggs laid on leaf sheath, larvae crawl down the plant between leaf sheaths to reach the apical meristem, on which they feed. Larval feeding causes formation of a tubular leaf sheath like gall. Pupae wriggle up along the elongated gall and drill an exit hole near the gall tip that allows emergence of adult fly. The gall formed from this fly is popularly known as 'silver shoot' or 'onion shoot' or 'anekombu' due to the creation of hollow,
Mamathad C

M. Sc. Student, Department of

Entomology, College of

Agriculture, V. C. Farm,

Mandya, Karnataka, India 
pale green or silvery white cylindrical tubes bearing a reduced leaf blade with ligules and auricles at their tips. Since from the beginning of the $20^{\text {th }}$ century, the gall midge is major threat to paddy cultivation in coastal Karnataka and gall midge has acquired the status of major pest in Cauvery command area and started spreading towards adjacent districts. Therefore, keeping this in view the present study was planned to know the information on the pest status in Cauvery command area and its adjoining districts.

\section{Materials and Methods}

To know the incidence of gall midge population in different location of Cauvery and Kabini command area, a rowing survey was conducted during kharif and rabi 2019 at different locations in Mandya district which includes six taluks viz., Maddur, Mandya, Srirangapatna, K. R. Pet, Pandavpura and Mallvalli. In Chamarajanagar district four taluks like Chamarajanagar, Yelandur, Kollegala and Hanur were covered. Likewise, in Mysore district about four taluks were surveyed and they are Nanjungud, T. Narsipura, K. R. Nagar and Mysore.

In each location, the infestation of gall midge was recorded on 30 and 60 days old crop across varieties cultivated in respective districts. In each location, the survey plot area was divided in to four quadrants approximately $200 \mathrm{~m}^{2}$. In each quadrant 20 hills were selected diagonally for observation. The information regarding the varieties are confirmed by the local farmers. The observations on the gall midge infestation was recorded by counting the number of plants with silver shoot and without silver shoot on hill basis (Vijaykumar et al., 2008) ${ }^{[13]}$.

The total number of silver shoots in each tiller was recorded on tiller basis. Further, the per cent plant damage on hill basis and per cent silver shoot on tiller basis was worked out as below.

$\%$ Damaged plants $=\frac{\text { Total number of infested plants }}{\text { Total number of plants }} \times 100$

$\%$ Silver shoots $=\frac{\text { Total number of tillers with ss }}{\text { Total number of tillers }} \times 100$

In each location the data on per cent plant damage and silver shoots was converted to 0-9 scale (SES, 2013) (Table 1). Further, the data on gall midge infestation in each surveyed location was processed, the mean and standard deviation was worked out for the interpretation of data.

Table 1: Standard Evaluation System for Rice gall midge

\begin{tabular}{|c|c|c|}
\hline Scale & Damage (\%) & Reaction \\
\hline 0 & No damage & Highly resistant \\
\hline 1 & $<1 \%$ & Resistant \\
\hline 3 & $1-5 \%$ & Moderately resistant \\
\hline 5 & $6-10 \%$ & Moderately susceptible \\
\hline 7 & $11-25 \%$ & Susceptible \\
\hline 9 & $>25 \%$ & Highly susceptible \\
\hline
\end{tabular}

Further, in each surveyed location, the per cent silver shoot, the information on days after planting, variety and duration of the variety was recorded.

\section{Results and discussion}

In Mandya district, the per cent silver shoot was ranged from 7.18 to 9.03 . The highest per cent silver shoot of 9.03 was recorded in the Mandya taluk this was followed by Maddur which recorded 8.70 per cent. Likewise, taluks like S. R. Patna, K. R. Pet and Pandavpura recorded the per cent silver shoot of $8.51,8.16$ and 7.72 , respectively. However,

Table 2: Incidence of Asian rice gall midge, Orseolia oryzae in Mandya, Karnataka, Kharif 2019

\begin{tabular}{|c|c|c|c|c|c|c|c|c|c|c|}
\hline District & Taluks & Lattitude & Variety & DAP & TP & DP & \% DP & TT & SS & $\% \mathrm{SS}$ \\
\hline \multirow{24}{*}{ Mandya } & \multirow{3}{*}{ Maddur } & \multirow{3}{*}{$\begin{array}{l}12.48^{0} \mathrm{~N} \\
77.03^{0} \mathrm{E}\end{array}$} & Jaya & 47 & 50 & 10 & 20 & 481 & 42 & 8.73 \\
\hline & & & IR-64 & 45 & 50 & 11 & 22 & 470 & 41 & 8.72 \\
\hline & & & VNR & 50 & 50 & 11 & 22 & 488 & 42 & 8.65 \\
\hline & \multicolumn{3}{|c|}{ Mean \pm SD } & $47.30 \pm 2.05$ & & $10.60 \pm 0.47$ & $21.30 \pm 0.94$ & $479.60 \pm 7.40$ & $41.67 \pm 0.47$ & $8.70 \pm 0.03$ \\
\hline & \multirow{3}{*}{ Mandya } & \multirow{3}{*}{$\begin{array}{l}12.52^{0} \mathrm{~N} \\
76.88^{0} \mathrm{E}\end{array}$} & IR-64 & 52 & 50 & 11 & 22 & 452 & 43 & 9.51 \\
\hline & & & BR 2655 & 45 & 50 & 12 & 24 & 455 & 38 & 8.35 \\
\hline & & & Jaya & 50 & 50 & 10 & 20 & 455 & 42 & 9.23 \\
\hline & \multicolumn{3}{|c|}{ Mean \pm SD } & $49.00 \pm 2.94$ & & $11.00 \pm 0.81$ & $22.00 \pm 1.63$ & $454.00 \pm 1.41$ & $41.00 \pm 2.16$ & $9.03 \pm 0.49$ \\
\hline & \multirow{3}{*}{ K. R. Pet } & \multirow{3}{*}{$\begin{array}{l}12.66^{0} \mathrm{~N} \\
76.49^{0} \mathrm{E}\end{array}$} & VNR & 48 & 50 & 9 & 18 & 470 & \begin{tabular}{|l|}
36 \\
\end{tabular} & 7.65 \\
\hline & & & Jyothi & 38 & 50 & 11 & 22 & 456 & 39 & 8.55 \\
\hline & & & Gangavathi sona & 46 & 50 & 8 & 16 & 460 & 38 & 8.26 \\
\hline & \multicolumn{3}{|c|}{ Mean \pm SD } & $44.00 \pm 4.32$ & & $9.33 \pm 1.24$ & $18.67 \pm 2.49$ & $462.00 \pm 5.88$ & $37.67 \pm 1.24$ & $8.16 \pm 0.37$ \\
\hline & \multirow{3}{*}{ Pandavpura } & \multirow{3}{*}{$\begin{array}{l}12.50^{0} \mathrm{~N} \\
76.57^{0} \mathrm{E}\end{array}$} & MTU 1001 & 55 & 50 & 8 & 16 & 445 & 35 & 7.86 \\
\hline & & & BR 2655 & 50 & 50 & 9 & 18 & 462 & 37 & 8.00 \\
\hline & & & Jyothi & 48 & 50 & 9 & 18 & 479 & 35 & 7.30 \\
\hline & \multicolumn{3}{|c|}{ Mean \pm SD } & $51.00 \pm 2.94$ & & $8.67 \pm 0.47$ & $17.33 \pm 0.94$ & $462.00 \pm 13.80$ & $35.67 \pm 0.94$ & $7.72 \pm 0.30$ \\
\hline & \multirow{3}{*}{ S.R.Patna } & \multirow{3}{*}{$\begin{array}{l}12.24^{0} \mathrm{~N} \\
76.42^{0} \mathrm{E}\end{array}$} & IR-64 & 35 & 50 & 10 & 20 & 481 & \begin{tabular}{|l|}
41 \\
\end{tabular} & 8.52 \\
\hline & & & Jaya & 45 & 50 & 10 & 20 & 489 & 42 & 8.58 \\
\hline & & & Gangavathi sona & 40 & 50 & 9 & 18 & 474 & 40 & 8.48 \\
\hline & \multicolumn{3}{|c|}{ Mean \pm SD } & $40.00 \pm 4.08$ & & $9.67 \pm 0.47$ & $19.33 \pm 0.94$ & $481.00 \pm 6.12$ & $41.00 \pm 0.81$ & $8.51 \pm 0.06$ \\
\hline & \multirow{3}{*}{ Malavalli } & \multirow{3}{*}{$\begin{array}{l}12.38^{0} \mathrm{~N} \\
77.05^{0} \mathrm{E}\end{array}$} & Jyothi & 53 & 50 & 8 & 16 & 471 & 35 & 7.43 \\
\hline & & & BR 2655 & 50 & 50 & 8 & 16 & 469 & 33 & 7.03 \\
\hline & & & Tanu & 52 & 50 & 9 & 18 & 465 & 33 & 7.09 \\
\hline & \multicolumn{3}{|c|}{ Mean \pm SD } & $51.67 \pm 1.24$ & & $8.33 \pm 0.47$ & $16.67 \pm 0.94$ & $468.30 \pm 2.49$ & $33.67 \pm 0.94$ & $7.18 \pm 0.17$ \\
\hline
\end{tabular}

DAP- Days after planting; TP- Total plants; DP- Damaged plants; TT- Total tillers; SS- Silver shoot

The least per cent silver shoot $(7.18 \%)$ was recorded in the Malavalli taluk (Table 7) (Figure 1).

Further, the infestation level of Asian rice gall midge was meticulously recorded in popular rice varieties. The most commonly cultivated varieties in the Mandya district are Jaya, Jyothi, BR 2655, IR-64 and Gangavathi sona. Among 
popularly cultivated varieties, IR-64 recorded the highest per cent silver shoot of 9.51, followed by 9.23 per cent silver shoot in Jaya at Mandya taluk. In Maddur taluk, the variety Jaya recorded the highest per cent silver shoot of 8.73 and it was followed by IR-64 $(8.72 \% \mathrm{SS})$ and least incidence of gall midge was recorded in private company variety VNR with 8.65 per cent silver shoot. Likewise, in S. R. Patna taluk the incidence of silver shoot was varied between 8.58 and 8.48 per cent. Among the popularly cultivated varieties Jaya recorded higher incidence (8.58 \% SS) and Gangavathi sona recorded lower incidence of gall midge (8.48 \% SS).

Similarly, the highest per cent silver shoot $(8.55 \%)$ was recorded in Jyothi variety at K. R. Pet taluk, followed by Gangavathi sona (8.26 \% SS) and least incidence of gall midge was observed in VNR (7.65 \% SS). In Pandavapura, BR 2655 variety recorded the highest per cent silver shoot of 8.00, which was followed by MTU 1001 (7.86 \% SS) and lower incidence of gall midge in the Jyothi (7.30 \% SS). In Malavalli taluk, the popularly cultivated variety Jyothi recorded higher gall midge incidence $(7.43 \% \mathrm{SS})$, this was followed by Tanu (7.09\% SS) and BR 2655 (7.03\% SS)
(Table 2).

The per cent silver shoot in different taluks of Chamarajanagar district varied between 7.27 to 8.70 . The highest per cent silver shoot was recorded in the Chamarajanagar taluk $(8.70 \%)$, this was followed by the Yelandur taluk which accounts for 8.36 per cent silver shoot. Similarly, the per cent silver shoot in Kollegala taluk was 7.67 and the least per cent silver shoot was recorded in the Hanur taluk $(7.27 \%)$.

The commonly cultivated varieties in these locations of Kabini command area were Jyothi, MTU1001, Jaya and Tanu. Among them, the variety MTU 1001 has recorded the highest per cent silver shoot $(9.17 \%)$, followed by Tanu with 8.60 per cent, and the least incidence of gall midge was observed in the variety Jyothi in Chamarajanagar taluk. Likewise, in Yelandur taluk, the variety Jaya recorded highest silver shoot per cent of 8.70 , which was followed by VNR $(8.29 \%$ SS) and lowest per cent silver shoot was recorded in variety BR 2655 (8.08\% SS). In Kollegala taluk, the popularly cultivated variety MTU 1001 .

Table 3: Incidence of Asian rice gall midge, O. oryzae in Chamarajanagar, Karnataka, Kharif 2019

\begin{tabular}{|c|c|c|c|c|c|c|c|c|c|c|}
\hline District & Taluks & Lattitude & Variety & DAP & $\mathbf{T P}$ & DP & $\%$ DP & TT & SS & $\% \mathrm{SS}$ \\
\hline \multirow{16}{*}{ C.R.Nagar } & \multirow{3}{*}{ C.R.Nagar } & \multirow{3}{*}{$\begin{array}{l}11.92^{0} \mathrm{~N} \\
76.94^{0} \mathrm{E}\end{array}$} & MTU 1001 & 48 & 50 & 9 & 22 & 469 & 43 & 9.17 \\
\hline & & & Tanu & 50 & 50 & 11 & 18 & 465 & 40 & 8.60 \\
\hline & & & Jyothi & 45 & 50 & 10 & 20 & 455 & 38 & 8.35 \\
\hline & \multicolumn{3}{|c|}{ Mean \pm SD } & $47.67 \pm 2.05$ & & $10.00 \pm 0.81$ & $20.00 \pm 1.63$ & $463.00 \pm 5.88$ & $40.30 \pm 2.05$ & $8.70 \pm 0.34$ \\
\hline & \multirow{3}{*}{ Yelandur } & \multirow{3}{*}{$\begin{array}{l}11.42^{0} \mathrm{~N} \\
76.57^{0} \mathrm{E}\end{array}$} & Jaya & 52 & 50 & 9 & 18 & 471 & 41 & 8.70 \\
\hline & & & VNR & 55 & 50 & 9 & 18 & 470 & 39 & 8.29 \\
\hline & & & BR 2655 & 46 & 50 & 10 & 20 & 445 & 36 & 8.08 \\
\hline & \multicolumn{3}{|c|}{ Mean \pm SD } & $51.00 \pm 3.74$ & & $9.33 \pm 0.47$ & $18.67 \pm 0.94$ & $462.00 \pm 12.02$ & $38.67 \pm 2.05$ & $8.36 \pm 0.25$ \\
\hline & \multirow{3}{*}{ Kollegala } & \multirow{3}{*}{$\begin{array}{l}12.15^{0} \mathrm{~N} \\
77.10^{0} \mathrm{E}\end{array}$} & Jyothi & 39 & 50 & 10 & 20 & 471 & 35 & 7.43 \\
\hline & & & MTU 1001 & 44 & 50 & 7 & 16 & 465 & 37 & 7.95 \\
\hline & & & Jaya & 51 & 50 & 8 & 14 & 460 & 35 & 7.60 \\
\hline & \multicolumn{3}{|c|}{ Mean \pm SD } & $44.67 \pm 4.92$ & & $8.33 \pm 1.24$ & $16.67 \pm 2.49$ & $465.30 \pm 4.49$ & $35.67 \pm 0.94$ & $7.67 \pm 0.21$ \\
\hline & \multirow{3}{*}{ Hanur } & \multirow{3}{*}{$\begin{array}{l}12.08^{0} \mathrm{~N} \\
77.30^{0} \mathrm{E}\end{array}$} & VNR & 49 & 50 & 8 & 16 & 455 & 34 & 7.47 \\
\hline & & & Tanu & 50 & 50 & 7 & 14 & 450 & 32 & 7.11 \\
\hline & & & Gangavathi sona & 47 & 50 & 9 & 18 & 455 & 33 & 7.25 \\
\hline & \multicolumn{3}{|c|}{ Mean \pm SD } & $48.67 \pm 1.24$ & & $8.00 \pm 0.81$ & $16.00 \pm 1.63$ & $453.30 \pm 2.35$ & $33.00 \pm 0.81$ & $7.27 \pm 0.14$ \\
\hline
\end{tabular}

DAP- Days after planting; TP- Total plants; DP- Damaged plants; TT- Total tillers; SS- Silver shoot; C.R.Nagar- Chamarajanagar

Recorded higher incidence of gall midge $(7.95 \% \mathrm{SS})$, this was followed by Jaya (7.60\% SS) and Jyothi (7.43\% SS). Among four taluks of Kabini command areas of Chamarajanagar district, the variety Tanu recorded the lowest per cent silver shoot $(7.11 \%)$ in Hanur taluk (Table 3 ). In all these locations the incidence of gall midge was above the economic threshold level and most of the farmers were not aware of the symptoms and loss caused by this internal feeder.

Among four taluks of Cauvery command area in Mysore district, the per cent silver shoot was varied between 6.95 and 8.71. The incidence of rice gall midge in Nanjungud taluk was found higher $(8.71 \%)$, and this was followed by T. Narsipura taluk $(8.45 \%)$. Likewise, the gall midge infestation at K. R. Nagar taluk was 7.84 per cent and the lowest per cent silver shoot (6.95\%) was recorded in Mysore taluk.

Among these taluks of Mysore district, the most commonly cultivated varieties were Jyothi, MTU 1001, Jaya, Tanu and VNR. The highest per cent silver shoot $(8.89 \%)$ was recorded in Tanu, and this was followed by MTU 1001 (8.81\% SS). However, the least per cent silver shoot was observed in Jaya $(8.42 \%)$ in Nanjungud taluk. Likewise, in T. Narsipura taluk the variety Jyothi has recorded highest per cent silver shoot $(8.72 \%)$, followed by Tanu ( $8.53 \%$ SS) and lowest incidence was observed in VNR $(8.12 \%$ SS). Further, the variety BR 2655 in K. R. Nagar taluk has recorded the higher incidence of gall midge with 8.07 per cent silver shoot, followed by Jyothi $(7.96 \% \mathrm{SS})$ and the least incidence was observed in the rice variety Gangavathi sona $(7.47 \% \mathrm{SS})$. However, the gall midge infestation at Mysore taluk was low (6.74\% SS) on variety Jaya compared to the remaining taluks. The incidence of rice gall midge on popularly growing rice varieties viz., MTU1001, VNR was 7.11 and 6.99 per cent silver shoot, respectively which was above the economic threshold level (Table 4).

Among three districts surveyed for the incidence of rice gall midge during 2019, the highest per cent silver shoot (9.03) was recorded in Mandya district followed by Chamarajanagar (8.70\% SS) and lowest per cent silver shoot of 6.95 was observed in Mysore district. Further, it was observed that the most of the popularly cultivated rice varieties over several decades viz., Jaya, Jyothi, BR 2655, MTU 1001 and Tanu were found highly susceptible to the infestation of rice gall midge. Among these varieties, Jaya occupied largest cultivable area in Mandya, Chamarajanagar and Mysore districts, and was found severely affected by the Asian rice gall midge. 
Table 4: Incidence of Asian rice gall midge, O. oryzae in Mysore, Karnataka, Kharif 2019

\begin{tabular}{|c|c|c|c|c|c|c|c|c|c|c|}
\hline District & Taluks & Lattitude & Variety & DAP & $\mathbf{T P}$ & DP & $\%$ DP & TT & SS & $\% \mathrm{SS}$ \\
\hline \multirow{16}{*}{ Mysore } & \multirow{3}{*}{ Nanjungud } & \multirow{3}{*}{$\begin{array}{l}12.11^{0} \mathrm{~N} \\
76.67^{0} \mathrm{E}\end{array}$} & Tanu & 50 & 50 & 10 & 20 & 472 & 42 & 8.89 \\
\hline & & & MTU1001 & 45 & 50 & 11 & 22 & 465 & 41 & 8.81 \\
\hline & & & Jaya & 49 & 50 & 11 & 22 & 463 & 39 & 8.42 \\
\hline & \multicolumn{3}{|c|}{ Mean \pm SD } & $48.00 \pm 2.16$ & & $10.67 \pm 0.47$ & $21.33 \pm 0.94$ & $466.60 \pm 3.85$ & $40.67 \pm 1.24$ & $8.71 \pm 0.20$ \\
\hline & \multirow{3}{*}{ T. Narsipura } & \multirow{3}{*}{$\begin{array}{l}12.20^{0} \mathrm{~N} \\
76.90^{0} \mathrm{E}\end{array}$} & Jyothi & 44 & 50 & 9 & 18 & 470 & 41 & 8.72 \\
\hline & & & Tanu & 51 & 50 & 10 & 20 & 469 & 40 & 8.53 \\
\hline & & & VNR & 54 & 50 & 9 & 18 & 468 & 38 & 8.12 \\
\hline & \multicolumn{3}{|c|}{ Mean \pm SD } & $49.67 \pm 4.18$ & & $9.30 \pm 0.47$ & $18.67 \pm 0.94$ & $469.00 \pm 0.81$ & $39.67 \pm 1.24$ & $8.45 \pm 0.25$ \\
\hline & \multirow{3}{*}{ K.R. Nagar } & \multirow{3}{*}{$\begin{array}{l}12.44^{0} \mathrm{~N} \\
76.38^{0} \mathrm{E}\end{array}$} & BR-2655 & 48 & 50 & 8 & 16 & 458 & 37 & 8.07 \\
\hline & & & Jyothi & 51 & 50 & 9 & 18 & 452 & 36 & 7.96 \\
\hline & & & Gangavathi sona & 49 & 50 & 9 & 18 & 455 & 34 & 7.47 \\
\hline & \multicolumn{3}{|c|}{ Mean \pm SD } & $49.30 \pm 1.24$ & & $8.67 \pm 0.47$ & $17.30 \pm 0.94$ & $455.00 \pm 2.45$ & $35.67 \pm 1.24$ & $7.84 \pm 0.26$ \\
\hline & \multirow{3}{*}{ Mysore } & \multirow{3}{*}{$\begin{array}{l}12.37^{0} \mathrm{~N} \\
76.65^{0} \mathrm{E}\end{array}$} & MTU1001 & 46 & 50 & 6 & 12 & 450 & 32 & 7.11 \\
\hline & & & Jaya & 50 & 50 & 7 & 14 & 445 & 30 & 6.74 \\
\hline & & & VNR & 48 & 50 & 9 & 18 & 443 & 31 & 6.99 \\
\hline & & Mean $\pm S$ & & $48.00 \pm 1.63$ & & $7.30 \pm 1.24$ & $14.67 \pm 2.49$ & $446.00 \pm 2.94$ & $31.00 \pm 0.81$ & $6.95 \pm 0.15$ \\
\hline
\end{tabular}

DAP- Days after planting; TP- Total plants; DP- Damaged plants; TT- Total tillers; SS- Silver shoot

Similar observation were recorded by Vijaykumar (2007) where, the incidence of Asian rice gall midge was up to 65.00 with silver shoot range from 8.80 to 19.20 per cent at different locations of coastal Karnataka viz., Mangalore, Udupi, Karkala, Belthangadi, Puttur and siddapur compared to southern parts of Karnataka viz., Madikeri, Mysore and Mandya, where, the incidence was in between 6.50 to 10.25 per cent silver shoot. Further, the infestation of rice gall midge and its severity among the varieties depends on the prevalence of local biotype population and their virulence spectrum and composition of biotype mixtures as observed by Vijaykumar et al. (2008) ${ }^{[13]}$. Further, the occurrence of leaf folder, yellow stem borer, gall midge, blue beetle, hispa, armyworm, horned caterpillar, green leafhopper, white leafhopper and brown plant hopper was reported by Prasad (2003) ${ }^{[9]}$ is in line with the present findings, who observed lower gall midge infestation (1 to 7\%) at Uttar Kannada district but Naing et al. (2008) ${ }^{[8]}$ reported higher incidence of rice gall midge in nursery as well as main field due to cloudy weather and drizzling compared to all other defoliators and internal feeders occurring on rice.

Pest monitoring done by Hembrom and Prasad (2014) [3] indicated that among 17 insect pests prevailed in the different stages of crop growth only six pests were observed as major and they include gall midge, stem borer, hispa, leaf folder and ear bug. Kumari et al. (2018) ${ }^{[7]}$ recorded per cent silver shoot at weekly intervals starting from 14 days after sowing and noticed the peak incidence of gall midge during the $39^{\text {th }}$ standard meteorological week (i.e., $24^{\text {th }}$ September to $30^{\text {th }}$ September). The incidence of gall midge was positively correlated with temperature whereas, sunshine hours showed negative correlation with incidence of gall midge.

The findings of Singh and Singh (2017) ${ }^{[12]}$ are found in close conformity with the present study who reported fortnightly observations of major insect pests at both vegetative and reproductive stage of paddy and they found the infestation of rice gall midge $O$. oryzae during reproductive stage of the crop when tiller formation has been initiated. Further, Prasad et al. (2018) ${ }^{[10]}$ reported that infestation of gall midge begins from $2^{\text {nd }}$ fortnight of July with lower incidence of 0.06 per cent silver shoot and infestation increases in the $2^{\text {nd }}$ fortnight of September with 34.40 per cent silver shoot. However, the incidence of pest declines from 6.80 per cent silver shoot in the $1^{\text {st }}$ fortnight of October with minimum of 4.10 per cent along with the hill damage of 20.40 per cent in $2^{\text {nd }}$ fortnight of October.

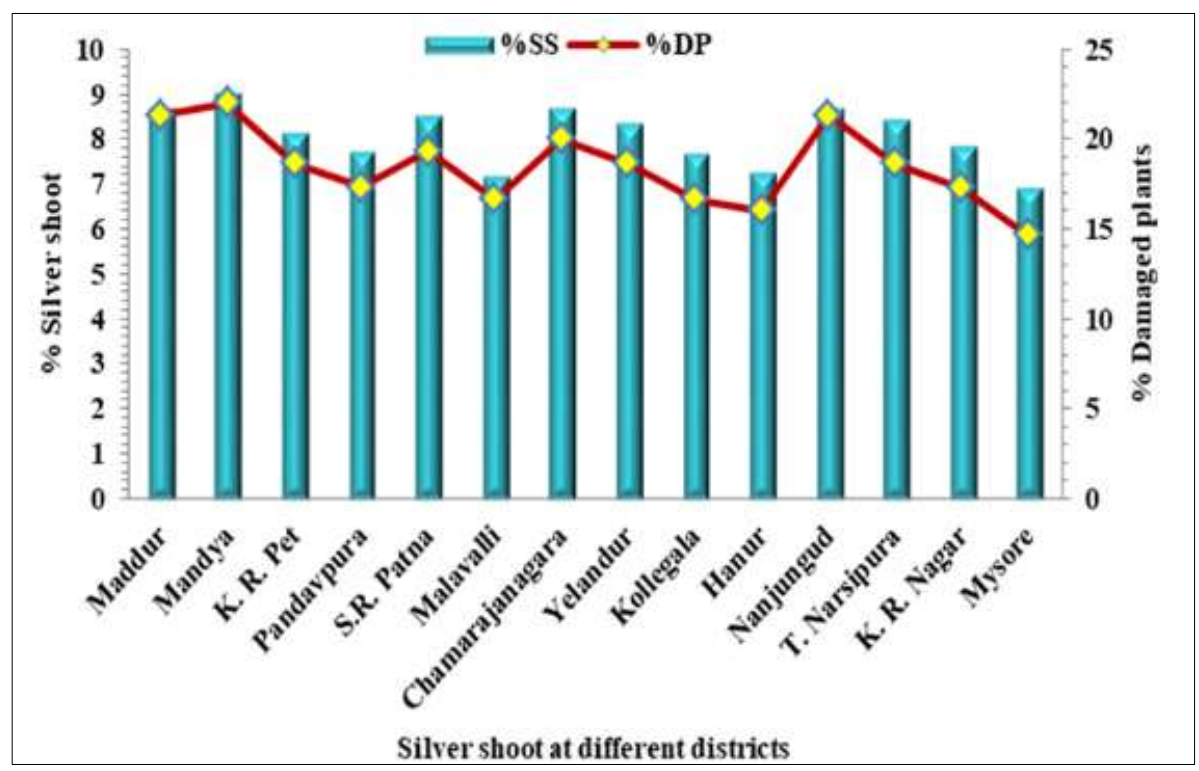

Fig 1: Gall midge infestation across different districts 


\section{Conclusion}

The average pest incidence in all the three districts surveyed was 7-9 per cent silver shoot which was above economic threshold level. The differences in the intensity of incidence across varieties might be due to genetical and climatic factors along with the activities of the pest prevailing in the respective location.

\section{References}

1. Bentur JS, Pasalu IC, Sharma NP, Prasada RU, Mishra B. Gall midge resistance in rice: Current status in India and future strategies. DRR Research Paper Series 01/2003. Directorate of Rice Research, Rajendranagar, Hyderabad, 2003, 20.

2. Chang TT. The origin, evolution, cultivation, dissemination and diversification of Asian and African rice. Euphytica 1976;25:435-44.

3. Hembrom L, Prasad R. 4, Integrated approach for the management of major insect pests of rice. M.Sc. (Agri.), Thesis, Birsa Agricultural Universities, Ranchi, Jharkhand, 2014.

4. IRRI (International Rice Research Institute), Standard Evaluation System for Rice. International Rice Research Institute, Los Banos, Philippines 2002.

5. Khush GS. Origin, dispersal, cultivation and variation of rice. Plant Mol. Biol 1997;35:25-34.

6. Krishnaiah NV, Kalode MB. Toxicological investigations against rice green leafhopper, Nephotettix virescens (Distant). Trop. Pest Manag 1986;32(1):44-48.

7. Kumari A, Prasad R, Prasad D. Effect of weather parameters on incidence and abundance of gall midge $(O$. oryzae) in rice (TN-1) grown in Ranchi, Jharkhand. J Entomol. Zool. Stud 2018;6(4):1329-1331.

8. Naing TAA, Kingsbury AJ, Buerkert A, Finckh MR. A Survey of Myanmar Rice Production and Constraints. J Agri. Rural Devel. Tropics Subtropics 2008;109(2):151168.

9. Prasad K. Survey on the incidence of pests of rice under rainfed low land ecosystem. Karnataka J Agric. Sci 2003;6(3):460.

10. Prasad R, Soren A, Hembrom L, Prasad D. Status of prevailing insect pest fauna associated with transplanted rice in Jharkhand. J Ecofriendly Agric 2018;13(1):60-64.

11. Rai M. Rice the cereal that feeds billion. Indian Farm 2006;56(7):62-64.

12. Singh S, Singh BK. Survey and fortnightly observation to find out major insect pests of rice crop (Oryza sativa) in Patna district of Bihar. J Entomol. Zool. Stud 2017;5(1):766-769.

13. Vijaykumar L, Chakravarthy AK, Gowda KNM, Thyagaraj NE. Economic threshold level of Asian rice gall midge, Orseolia oryzae (Wood-Mason) (Diptera: Cecidomyiidae) in Coastal Karnataka. Curr. Biotica 2008;2(2):146-153.

14. Vijay Kumar L. Studies on identification, virulence pattern, changing scenario and host plant interactions in Asian rice gall midge biotypes, Orseolia oryzae (WoodMason) (Diptera: Cecidomyiidae) in Karnataka, South India Ph.D., (Agri.), Thesis, Universities of Agricultural Sciences, Bangalore, 2007. 